\title{
A FLORISTIC STUDY OF FORESTS AND BOG VEGETATION, NORTHWESTERN MINNESOTA ${ }^{1}$
}

\author{
C. R. JANSSEN ${ }^{2}$ \\ Limnological Research Center, University of Minnesota, Minneapolis, ${ }^{M}$ inn. \\ (Accepted for publication May 15, 1967)
}

\begin{abstract}
Single vegetation plots in forests and bogs in the deciduous and coniferoushardwood formation in northwestern Minnesota were studied according to the field methods of the Zürich-Montpellier system. Plots and species were arranged so that the greatest coincidence of occurrences was obtained. Species that show approximately similar amplitudes were united in sociological groups. Plant communities typified by these groups were placed in a hierarchy. The plant communities appear to intergrade but are not completely continuous. Definite concentrations of occurrences remain present in the ordination. Fourteen main types of vegetation are recognized. Their relations to the environment are discussed, and their relations to vegetation in other regions are indicated.

Thirteen main types of vegetation (alliances) are recognized in the Itasca State Park region. Lowland vegetation has been divided into five alliances. In three of them the pathway of lake filling, starting in a eutrophic sedge mat and proceeding towards a mesotropic Picea mariana bog forest, is depicted. The two remaining lowland types represent eutrophic swamp forest of Fraxinus nigra and Ulmus americana on shallow peat or young alluvial soils. Upland forests have been divided into three "rich" deciduous types and five "poor" coniferous types. The rich types are represented by Tilia americana forests, Acer saccharum forests, Quercus rubra forests, and Populus tremuloides-Quercus sp. forests, all showing representatives of the rich flora of the mesic Tilia-Acer forest. The coniferous forest types are represented by Populus tremuloides-Quercus sp. forests and closely related Pinus resinosa-Pinus banksiana forests, Pinus banksiana forests on sandy outwash soils, and Abies balsamea forests in a young stage of development. Of these types the Pinus banksiana forest is floristically the best defined.
\end{abstract}

\section{INTRODUCTION}

The present study was not undertaken for phytosociological purposes only. The fieldwork was done between 1962 and 1964 to determine the composition of the vegetation types in the region and to put the present vegetational pattern in a context that could be used in interpreting the pollen assemblages that record the development of bog vegetation in a small pond (Janssen 1967). The region investigated, an area about 50 miles long and 24 miles wide in northwestern Minnesota, belongs to the extension of Rowe's (1959) Great Lakes-St. Lawrence forest region across the international boundary. This transitional belt between the deciduous forests in the south and coniferous boreal forest in the north, called Lake Forest by Weaver and Clements (1938), includes both conifers (Tsuga canadensis, Picea glauca, Abies balsamea, $P$ inus strobus, and $P$. resinosa) and deciduous trees (Acer saccharum, Fagus grandifolia, Tilia americana, Betula lutea, Ulmus spp., and Quercus spp.). Towards the south the coniferous elements drop out; towards the north they prevail.

${ }^{1}$ Contribution No. 37, Limnological Research Center, University of Minnesota; Mededelingen van het Botanisch Museum en Herbarium van de Rijksuniversiteit te Utrecht No. 277 (1966).

2 Present address: Batanical Museum and Herbarium, State University, Utrecht, Netherlands.
In the boreal forest Pinus resinosa and $P$. strobus are absent, and only a few deciduous elements remain (Fig. 1).

The conifer-hardwood region in Minnesota belongs to Braun's (1950) hemlock-white pine-northern hardwoods region. All of the above species are present except $T$ suga canadensis and Fagus grandifolia. Between the conifer-hardwood region and the prairie is a narrow belt of deciduous forests. This may be considered a northwestern extension of the Big Woods section of Braun's maplebasswood forest region. It contains the same tree species present in the conifer-hardwood region except for the conifers. However, it does not have such tree genera as Carya, Juglans, and Celtis, which occur farther south in the state. In the transition between the narrow deciduous forest belt and the prairie, there locally occurs a $Q$ uercus macrocarpa savanna, in which shrubs play an important part.

The phytosociological data in this study cover vegetation types in the conifer-hardwood, deciduous, and savanna formations mainly in townships T143-144N, R32-41W (Fig. 1). This is essentially McAndrews' (1966) Itasca transect, but without the prairie sections. Data obtained from a region outside the Itasca transect (bog communities from the Lake Agassiz lowland) have been in- 


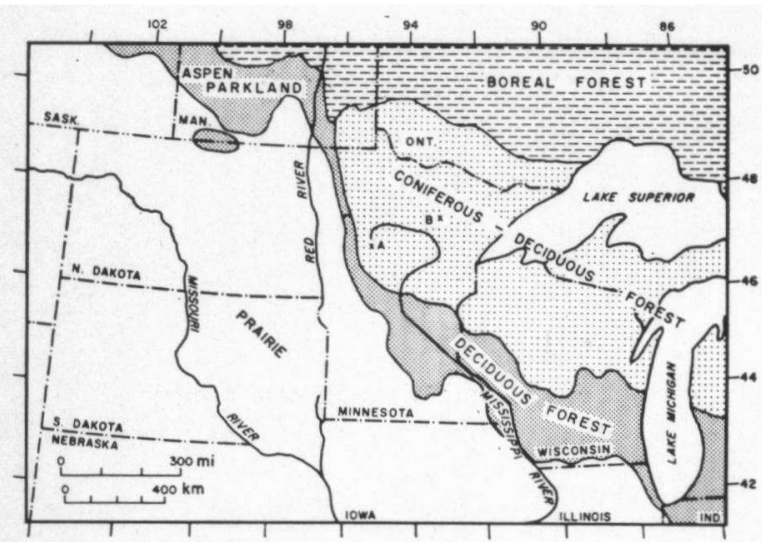

FIG. 1. Map of major vegetational formations of Minnesota and adjacent areas, showing location of Itasca State Park area (A) and Myrtle Lake (B).

cluded to show the contrast with lowland vegetation types in the Itasca State Park region. These data are from the Myrtle Lake region in northcentral Minnesota (Koochiching County, T163$165 \mathrm{~N}, \mathrm{R} 23-26 \mathrm{~W})$. The vegetation in the Itasca transect is related to these surrounding formations, namely the boreal forest formation, the prairie formation, and the deciduous forest formation.

This study is not the first attempt to classify the vegetation of northern Minnesota. Cooper (1912), working on Isle Royale in Lake Superior adjacent to northeastern Minnesota, described plant communities mainly for successional considerations. In fact, most of the older literature deals with climax problems (Cooper 1912, Bergman and Stallard 1916, Lee 1924, Kell 1938). Some of the presently described vegetation types may be found in these studies. The types described in the present study, however, are not based on successional or ecological features, although such features will be considered because they are so striking.

\section{Location, Climate, and Soil}

Most of the relevés were taken in an area 45 by 10 miles in Hubbard, Clearwater, Becker, and Mahnomen Counties (Fig. 2), with a concentration near Lake Itasca in Itasca State Park (Fig. 3 ). The area is deeply covered by calcareous drift deposited during the Wisconsin glaciation. The Big Stone Moraine of the Des Moines Lobe is composed of silty till, whereas the Itasca Moraine of the Wadena Lobe consists of sandy loam till (Wright 1962). The textural differences are reflected in the soil types, respectively WaukonBarnes and Nebish-Rockwood (Arneman 1963). Both soil types have a forest profile, but on the Itasca Moraine the soils have been leached to a greater depth and are therefore less fertile. The least fertile and most droughty soils are found in outwash plains (Allway and McMiller 1935). In the Itasca area are two large areas belonging to these soil types, the Twin Lakes and Lake George outwash plains, as well as several less extensive outwash areas in smaller drainageways.

West of the deciduous forest formation at the crest of the Big Stone Moraine are mixtures of forest and prairie soils (Buell and Cantlon 1951), in the Quercus macrocarpa savanna formation of McAndrews (1966). Because of the high degree of cultivation here the only forests existing today are farm woodlots. Relevés $148,149,151,152$,

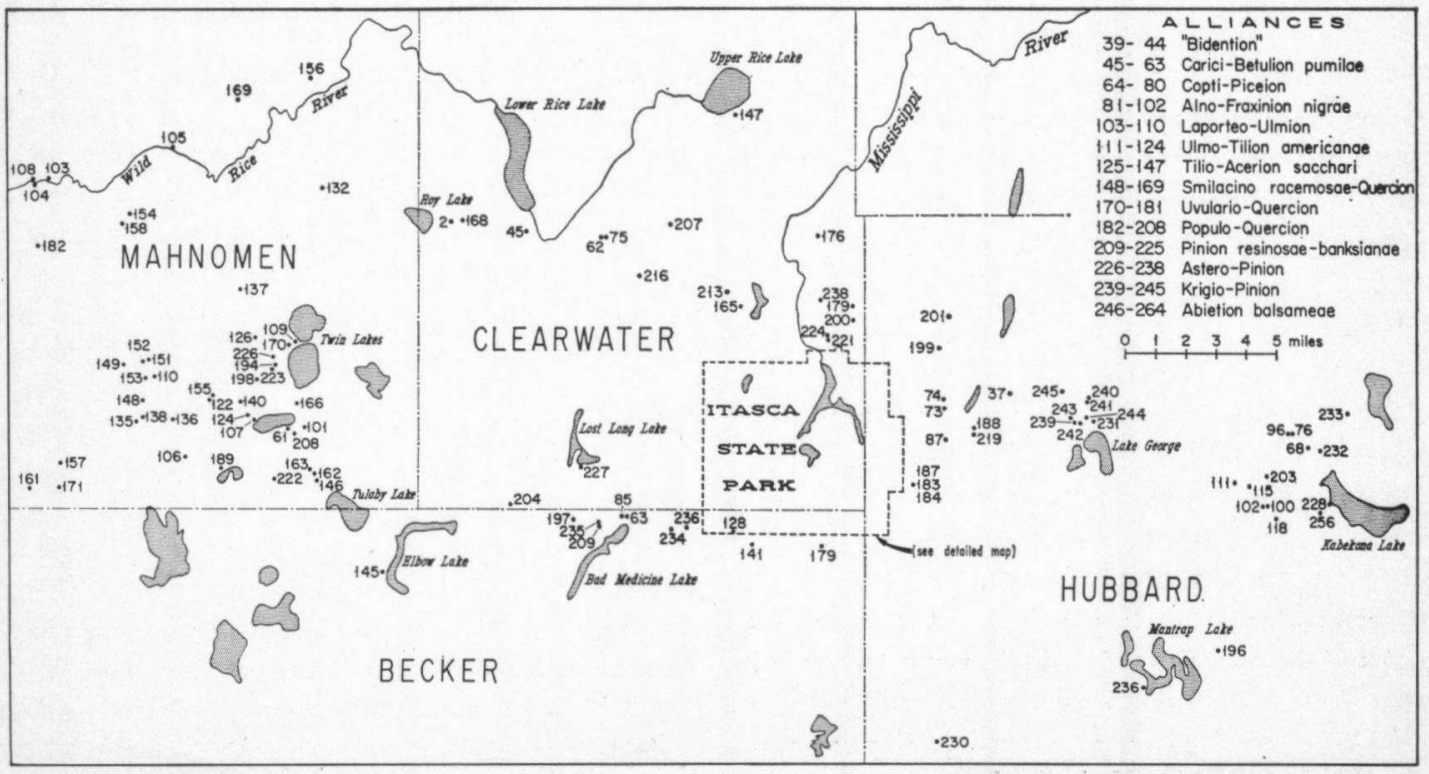

FIG. 2. Map showing location of relevés in area near Itasca State Park. 


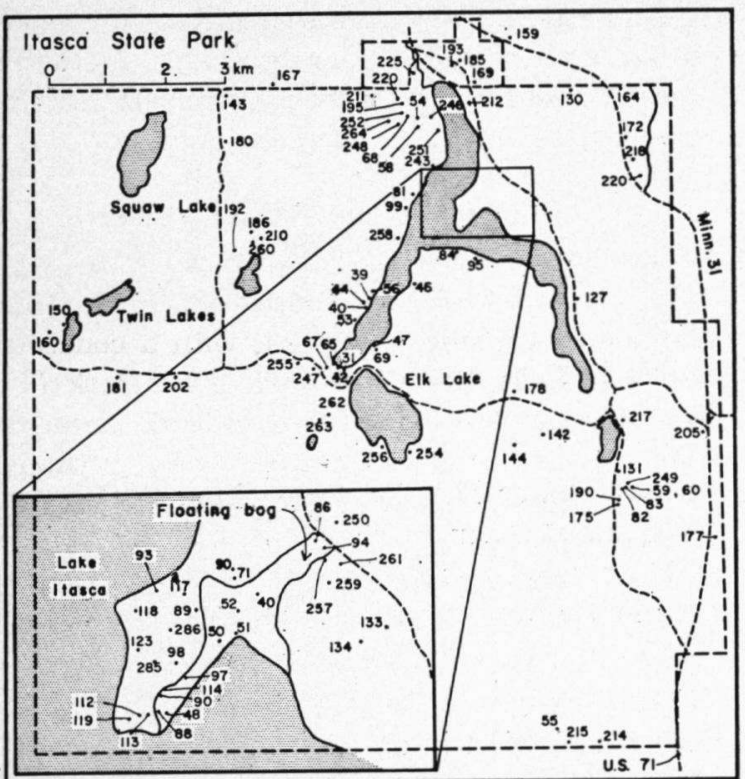

FIG. 3. Map showing location of relevés in Itasca State Park.

$153,154,157,158$, and 161 belong to this category. Relevés from groves on the Erskine Moraine west of Mahnomen County proved to fit badly in the ordination of plots to the east and accordingly have been omitted (see further comments).

\section{Vegetation Analysis}

This survey does not include all vegetation types in the region. Types were selected that were most likely to be important in the interpretation of the pollen diagram. The survey deals with forests, but in addition data have been included from lowland vegetation types that are part of the successions in lake filling and in which trees may be absent. Not included in this study are submerged vegetation, upland pioneer vegetation, lowland and upland shrub types, and roadside communities. The vegetation was studied between June and September. The early spring flora may therefore be insufficiently represented, especially in the Acer saccharum forests.

For the study of the vegetation composition a single plot analysis was used. These vegetation plots were studied using the methods of the Zürich-Montpellier school of phytosociology (Braun-Blanquet 1951). Quantity of the various species was estimated according to the following combined 7-point scale of cover and abundance. A second symbol indicates sociability.

\section{Indices of cover-abundance}

5. Covering more than three-quarters of the area

4. Any number of individuals covering onehalf to three-quarters of the area

3. Any number of individuals covering onequarter to one-half of the area

2. Very numerous or covering at least $5 \%$ of the area

1. Plentiful but of small cover value

t. Sparsely present, cover very small

r. Single occurrence

\section{Indices of sociability}

.1 Growing one in a place

.2 Grouped or tufted

.3 In troops, small patches, or cushions

.4 In small colonies, extensive patches, or carpets

.5 In great crowds, pure populations

A releve consists of an annotated list of the vegetation on a relatively large plot that must fulfill three criteria.

1. The plot should be large enough to contain all the species of the community. The minimum size is determined by selecting a small plot, tallying the species encountered, then enlarging the plot until no new additions to the tally list can be made. The minimum size in forests will be larger than in herbaceous vegetation (cf. Ellenberg 1956). In my study, plots in forests usually measure 225 or $400 \mathrm{~m}^{2}$.

2. The environmental complex, e.g. direction of exposure, should be constant, as far as can be seen without measurement.

3. The vegetation in all the strata should be as homogeneous as possible, as far as can be inspected visually. All the species (except single occurrences) should occur in every part of the plot. This means, for instance, that usually the fringe of a forest, where it borders a creek or a road, has not been included in a plot, because here lowland species, especially roadside species, may penetrate the forest. If the trees are large it may be difficult to fulfill the requirement of homogeneity in the tree layer. Then only a few trees are present in the relevé, and estimates of cover are useless. In these cases the size of the plots was expanded, while homogeneity in the other vegetation layers was maintained if possible. It becomes increasingly difficult, however, to scan such a large area in inspecting the homogeneity of the shrub and herb layers. Estimates of cover in these vegetation layers therefore are based upon 
the original size of the plot. The degree of cover refers to the projections of the circumferences of the individual species on the ground.

The relevés have been arranged according to presence or absence of the species. Relevés that have a great number of species in common have been placed together. Species have been placed in sociological groups, which consist of species that show comparable sociological amplitudes (Iversen 1954, Scamoni and Passarge 1959). Sociological groups were used by Doing (1962) to characterize wood and shrub communities in the Netherlands. They are approximately equivalent to ecological groups (Duvigneaud 1946), because both reflect environmental conditions. As Scamoni and Passarge (1959) and Doing (1962) point out, however, they include the factor of competition, unlike ecological groups.

In practice, sociological groups were established by plotting all the relevés more or less randomly on a large sheet of paper and then shifting the columns and rows by trial and error until groupings were obvious. Basically this is a numerical method carried out by hand. The results are displayed in three tables (envelope under rear cover) which may be placed in echelon. The biggest departure from arrangement on the basis of presence/ absence is in Table 1, where the unit labeled "transition" shows a position in the arrangement also based on geography and assumed succession. The left column in each table lists the plant species arranged in sociological groups. Each species occurs only once in the column. The composition of the sociological groups in each table is the same, except for omissions from one table because of absence or very low presence. An exception to this rule is made in group 8 , which has the largest sociological amplitude. In this group occur species that are common in almost all the forest types in the region. Moisture is probably the limiting ecological factor for group 8 in the forest analyzed in Tables 1 and 2 ; for those of Table 3 , it is the nutrient content of the soil. The species involved probably do not react in the same way to these factors. Therefore in Table 3 the species of group 8 have been arranged in a different way.

Species that show a very low presence in a table have not been included in the sociological groups, but their occurrences have been listed on the right side of each table.

At the top of each table are data about the location of the relevés, the structure of the vegetation, the exposure, the size of the relevés, and the number of species in each relevé. In case there is more than one tree or shrub layer, separate height and cover values for these layers are indicated by 1,11 , and 111 . The counties, indicated by abbreviations, are Hubbard, Clearwater, Mahnomen, Becker, and Koochiching.

Juvenile tree stages may occur in the shrub and herb layer of the forest, and juvenile shrubs may occur in the herb layer. In these cases an " $h$ " (herb) or "s" (shrub) is added after the notation of cover/abundance-sociability. For several species this is so common that a special row in the tables has been added; the species names in the sociological groups then have been provided with a notation $\mathrm{T}, \mathrm{S}$, or $\mathrm{H}$ for tree, shrub, or herb layer.

In some cases more than one stratum in the tree layer may be recognized. If a species occurred in the overstory, the notation is underlined (e.g. 5) ; if in the understory, it is roofed (e.g. $\hat{3}$ ). An " $x$ " is used in case a species occurred in the sample plot but in an environment not typical for the site. Most commonly this applies for species occurring on stumps in otherwise lowland habitats.

\section{Identification of Plant Communities}

Plant communities have been identified by combining sociological groups. Related communities have most of the sociological groups in common. In some cases the sociological amplitude is so narrow that the group is made up of species that are (locally) confined to a particular community. A glance at the tables shows how complex the interrelations of the communities are. The most striking feature is a gradient running through the three tables from the left top to the right bottom. Most of the species are not absolutely restricted to one segment of the vegetation. In many cases species are present outside their main occurrence. Moreover, it is often difficult to draw sharp boundary lines between neighboring communities. The communities that are floristically best characterized are the most specialized ones: forests on acid organic soils and forests on very poor sandy outwash soils. Other communities are floristically gradational into each other. The overall impression from the tables is that the vegetation is essentially a continuum in which delimitation of plant communities can only be arbitrary. This concept of vegetation is essentially that of Gleason (1926) ; it has been developed by workers at the University of Wisconsin (Curtis and McIntosh 1951, McIntosh 1958, Curtis 1959) and others.

It often has been claimed that the possibilities in recognizing distinct plant communities depend on the method followed. The Zürich-Montpellier system is said to be subjective because only homo- 
geneous sample plots are selected (Goodall 1963). The clear distinctions between the plant communities thus may be a result of leaving aside transitional vegetation. On the other hand, much of the basis for the continuum might be the result of studying large stands in a large area rather than smaller homogeneous vegetation plots in a restricted area. In spite of the fact that the field methods common in continental Europe have been used in the present study and that the area is restricted in size, overlap of sociological amplitudes is more common than groups that are confined to particular units. The continuous nature of the vegetation pattern therefore is more striking than the discontinuities in the tables. Poore (1955a, 1955b), applying continental methods to Scottish Nardus stricta-Carex vegetation, came to the same conclusion.

This procedure of arranging the relevés is not exactly the same, however, as that used by the Zürich-Montpellier school of phytosociology, in which plant communities are established on the basis of characteristic and differential species, and in which a hierarchic classification is erected that comprises units of lower and higher rank. In the tables presented here, correlation among the various plant species is established by means of sociological groups. Such a procedure is essentially an ordination of the data as opposed to a classification (Goodall 1954) and is, in fact, the same way of working out the data as developed at the University of Wisconsin. The method of establishing correlations is much more primitive, however. It does not make use of the highly evolved statistical methods of the Wisconsin group, nor does it allow presentation of the data in a multidimensional picture showing environmental gradients (Bray and Curtis 1957, Maycock and Curtis 1960, Bakuzis 1960). It is difficult to press a multidimensional scheme of relationships into a linear scheme (Gams 1941, p. 206, 212). This drawback is best illustrated in Table 3 , where a sharp floristic break is present between relevés 245 and 246. As mentioned above, two environmental gradients are involved here. In the table as it is now the transition from the Pinion resinosae-banksianae to the Astero-Pinion and Krigio$P$ inion is best illustrated. The Pinion resinosaebanksianae shows such a transition to the Abietion balsameae as well but along another gradient. This way of presentation, however, has the advantage, in common with the Zürich-Montpellier approach, that the species composition of each vegetation plot remains visible.

There is a possibility that the continuous nature of the vegetation is not largely a result of the methods followed, but that it also may be explained by features of the vegetation itself. In western Europe natural and seminatural vegetation no longer exists, for remnants of forests frequently have been split up in space during 5,000 years of agricultural practice. This has favored development of distinct communities. In contrast, in the Upper Midwest intensive agriculture has been active for only about 100 years. Stands have not been separated so much nor so long. Under such circumstances the continuous nature of the vegetation is more noticeable.

The establishment of sociological groups is the main purpose of this study. It would be contrary to the concept of a continuum to try to delimit definite plant communities. However, the continuum as presented in the tables is not completely continuous. At many places distinct concentrations of occurrences can be seen. They may be called noda (Poore 1955b) or clusters (Goodall 1954). It is around these noda that lines can be drawn to delimit plant communities. Solid lines were used where the noda are clearly outstanding and where occurrences are clearly clustered, and dotted lines where the delimitation of noda is uncertain, usually because of a. low presence of the species. Obviously this can be done in an arbitrary way only. It helps, however, to focus on the noda to read the tables more easily.

The nodal concept of the community also is recognized by Tüxen (1955, p. 159), who stressed the type character of the community: "Das Klare und Präzise an einem solchen Typus ist immer sein Kern, nicht sein Rand. Es gëhort zum Wesen eines Typus dass er keine scharfen Grenzen haben darf." So defined it is congruent to Goodall's clusters, and it comes close to the concept of continuum. An ordination of grassland stands in Saskatchewan by Looman (1963), based on continental premises, seems to indicate, however, that vegetational clusters may well be separated from each other.

The procedure here used, leading to the recognition of clusters, may be compared with that of recent statistical approaches. Lambert and Williams (1962) described an analysis that blends their earlier described normal association analysis ( $R$ analysis: plots arranged on the basis of species; Williams and Lambert 1959) with their inverse association analysis ( $Q$ analysis: species arranged according to plots in which they occur; Williams and Lambert 1961). Shifting rows to arrive at sociological groups is essentially a $Q$ 
type of analysis, and shifting columns is an $R$ type of analysis.

An additional advantage in delimiting plant communities is that it is easier to refer to them, a matter much more difficult in a scheme stressing the continuum. The same point has been made by Goodall (1963).

It remains to be seen whether clustering would appear if we did not insist on the homogeneity of the plots studied. Such a requirement results in a loss of information (Goodall 1963), but it may be defended because this simplification enables us to evaluate the factors of the environment more easily.

In order to show the floristic correlations, the various plant communities are classified in a hierarchic system. In some cases the sociological groups are treated the same way, but only to two levels. At the top of each table is a scheme of plant communities arranged on different levels. This scheme is by no means the only one that can be made by combining sociological groups. It may be possible to combine the sociological groups in a different way, resulting in communities showing a different species composition. The combinations here presented have been made according to what seemed to the author the most logical way. The procedure used is as follows :

Communities that are best defined floristically, physiognomically, and ecologically have been put as much as possible on the level of the alliance. Such a treatment is contrary to the procedure of the Braun-Blanquet methods sensu stricto, in which communities so defined are put on the level of the association (Braun-Blanquet 1959). Their placement on the alliance level, however, makes the system better balanced upwards and downwards. Moreover, many of the units are comparable to units recognized in Europe that are also on the level of the alliance and that are also strongly characterized ecologically (e.g. AlnoFraxinion v.v. Alnion incanae).

The communities have been named in the traditional way common in continental Europe. One might question whether this is justified. In the classical continental approach the association is identified by characteristic species and the subassociation by differential species. In my scheme such a strong connection is not present. I favor the European approach, however, because the principle of establishing and classifying communities on the basis of floristics lies very much at the base of continental ecology. The alternative would have been using common names. This, however, would introduce confusion with communi- ties established on the basis of other characteristics.

In the following pages a description will be given of the recognized plant communities. It would be easy to do this by making formal statements about differential species and characteristic species of classes, orders, alliances, and associations. There are two main reasons to avoid such an approach, however.

1. The sociological groups may be combined differently into other plant communities that are no less valid than the ones here established. Under such circumstances it would be irrelevant to assign such. groups formally to plant communities.

2. There is no proof that the composition of the sociological groups is the same in another area. In a different climate with a slightly different flora the changed competitive conditions may result in a different make-up of the sociological groups. Some examples may illustrate this. In our tables Ledum groenlandicum is restricted to moss heath and to Larix laricina and Picea mariana forests on peat. Approximately 100 miles towards the north. closer to the boreal forest formation, however, it is not uncommon to find Ledum in Pinus banksiana forests on well-drained mineral soils. The same applies for northern Ontario (Hustich 1955). Pinus banksiana itself, moreover, is more commonly associated in the north with species that are typical for bogs in our region. It may even occur on shallow peat (M. L. Heinselman. bersonal communication). In Wisconsin Curtis (1959, p. 224) states that Pinus banksiana mav achieve as high as $100 \%$ dominance in certain bogs. In Newfoundland (Damman 1964) Picen mariana forests are present on well-drained mineral soils associated with species that in the Lake Itasca area are either tvpical upland or lowland species.

Pinus strobus in our region is strictly an upland species, but on the fringe of its distribution area it occurs in bogs (Curtis 1959, p. 205, 223). The sociological groups therefore may have only a local validity, and it does not make sense to assign them formally to plant communities valid over a larger region.

The sociological groups thus will tell us in principle how species are correlated with each other in this part of Minnesota only. Because of the local value of the sociological groups, one might question whether units of higher rank should be recognized on the basis of this local low-intensity study. The history of the erection of the vegetational system in Europe has been that first the units of lower rank were recognized from local studies; later, when a sufficient number of such studies was 
available, units of higher rank were established. In the present study, units of high rank have been delimited and named so that they may be easily compared with the vegetation in other regions. For the same reasons van Donselaar (1965) described classes and units of lower rank in the savannas of Dutch Guiana.

The shifts in the sociological groups that occur in other areas do not affect the basic structure of the system. An investigation of the literature shows that the main trends evident in the Itasca tables is valid elsewhere in the forested regions of the Upper Midwest. In the Wisconsin studies, for example, any character of the vegetation (usually the importance value) is plotted against an environmental gradient (Curtis 1959). Species may be arranged in groups that show the same distribution along the gradient. Many such groups are more or less similar to the Itasca sociological groups. In such an arrangement, however, the species appear to be more tolerant towards environment than in the Itasca study. But even in the restricted area of the Itasca transect the arrangement of the sociological groups begins to blur. In Table 2 in part of the relevés belonging to the Diervilleto-Quercion, species of sociological group $6 \mathrm{~b}, 6 \mathrm{c}$, and $7 \mathrm{~b}$ occur that otherwise are characteristic for the Ulmo-Tilion and LaporteoUlmion. This happens mainly in the relevés from the most western part of the transect, situated in McAndrews' Quercus savanna. According to McAndrews (1966), west of the Big Stone Moraine there is an abrupt drop in precipitation from 23-25 inches/year in the deciduous/hardwood forest to 18.3 inches/year in the prairie, because of an orographic effect. The vegetation pattern would have been clearer if the relevés west of this boundary were excluded. West of the Quercus savanna there is on the Erskine Moraine a southern outlier of the aspen parkland of Manitoba, and the blurring of the arrangement is even stronger. This may indicate that the pattern of vegetation arrangement as is shown in this paper is in detail not much applicable beyond the formation.

The variations in the sociological groups that occur in other regions are very interesting, but an evaluation lies beyond the scope of the present work.

The sociological groups comprise species that show more or less the same requirements towards the environment. Apart from competition they therefore may be considered ecological groups. In the present study no measurement of the environment has been made. But one may commonly make general statements about the ecology of the sociological groups by comparing the communities of the Itasca study with approximately the same vegetation types from which data on the environment are known. Many features in the tables, however, remain ecologically unexplainable at present.

\section{Lowland Communities}

The lowland communities may be divided into three major units by means of five sociological groups. (1) The class Kalmio-Chamaedaphnetea contains species from sociological group 1 only. (2) The order Fraxinetalia nigrae has species combinations of sociological groups 2, 3, 4, and 5 . (3) An intermediate group of communities has the exclusive presence of sociological group 2 but in addition quite a number of representatives of groups $1,3,4$, and 8 . This is a very heterogeneous group, comprising both well-developed forests and herb vegetation. Because of these structural and physiognomic differences, it seems better not to unite them all in a class or even an order. It will be provisionally termed the "Thelypterideto-Piceetea" from Dryopteris thelypteris (group 2d), which shows a high presence here.

\section{Kalmio-Chamaedaphnetea}

Most of the releves for this class come from the Myrtle Lake region, an extensive patterned peat bog on the bed of the former glacial Lake Agassiz in north-central Minnesota (Heinselman 1963). This area is mainly covered by muskeg poor in species; trees, where present, are commonly stunted and widely spaced. Typical for this type of vegetation are representatives of sociological group $1 \mathrm{~b}$.

The relevés can be divided into the LaricetoChamaedaphnetum (group 1c) and the PicetoChamaedaphnetum (group 1f). Representatives of group la are abundant in hollows of string bogs (Heinselman 1963); this group may be analogous to the European Scheuchzerietalia palustris, which also contains Carex limosa and Scheuchzeria palustris and occurs in similar habitats. The data are too scanty, however, to unite the few relevés of group 1a into an association.

Chamaedaphne calyculata seems to find optimal conditions in open situations; Ledum groenlandicum, however, shows the reverse trend and is especially abundant in the last two releves of the Piceto-Chamaedaphnetum, where Picea mariana shows its highest cover and provides the most shade. Andromeda glaucophylla is most abundant in the Lariceto-Chamaedaphnetum. According to Cooper (1912) and Stallard (1929) it favors 
especially the wetter sites, whereas Chamaedaphne occupies the drier parts in a bog. They and Conway (1949) agree that Andromeda is characteristic of the younger parts of the moss heath formation. My table shows essentially the same.

The Kalmio-Chamaedaphnetea have been described in several boreal regions of North America. Heinselman (1963) calls this type the Sphagnumblack spruce-leatherleaf muskeg: his table comparing Picea types in the Agassiz lowland shows an absence of the species of group 2, as in our tables. The muskegs are also known from various parts of Canada, e.g. Alberta (Moss 1953), Ontario (Hustich 1955), Manitoba (Ritchie 1960).

\section{"Thelypterideto-Piceetea"}

The relevés found in this group of communities come mostly from the smaller basins in the Itasca area. Species from sociological group 3 and even 4 occur on peats in the marginal zones close to the upland, indicating that the nutrient content of the substrate must be higher than in the KalmioChamaedaphnetea. The number of species per relevé is higher. Larix laricina and Picea mariana form much denser stands and are much taller.

The arrangement of the relevés shows essentially the course of lake filling in the minor basins in the Itasca area. Ecological data from comparable bogs (Kurz 1928, Conway 1949, Clausen 1957) indicate that the accumulation of peat is accompanied by decreasing base content of the soil, decreasing $\mathrm{pH}$, and decreasing moisture. Our tables show how the species combinations change in response to the changing environmental conditions.

\section{Alliance 1: The "Bidention"}

The Bidenteto-Typhetum latifoliae. This association is sometimes found at the edge of the floating mat (see also Kurz 1928, Gates 1942, and Conway 1949), at the inlets of small streams, and in depressions of cultivated areas, presumably in a base-rich environment. Indeed work on cattail marshes in Michigan (Segadas-Vianna 1951) indicates a high $\mathrm{pH}$ and a high content of bases in the soil. The Bidenteto-Typhetum represents the most eutrophic stage in the hydrarch successions.

The community is not optimally represented in the table. The cattail marshes in depressions in cultivated areas have not been studied systematically, so it seems better to describe this type only as an association and not an alliance.

Sociological groups 2a, 2c, 2d, and part of 3a (Typha latifolia, Bidens cernua, and Impatiens capensis) are especially represented. The same species occur in cattail stands in Michigan (Segadas-Vianna 1951) and Wisconsin (Curtis 1959). Phragmites communis, commonly dominant in comparable vegetation in Europe (ScirpetoPhragmitetum), does not play an important part in the vegetation here. Where Phragmites communis occurs, however, it occupies the same sites as Typha latifolia at the edge of the mat (e.g. Floating Bog at Itasca State Park). Typha mats with much Phragmites have been described in north-central and northeastern Minnesota (Stallard 1929).

\section{Alliance 2: The Carici-Betulion pumilae}

This alliance can be divided into two associations, the Cariceto-Betuletum pumilae and the Saliceto bebbianaeLaricetum, by means of sociological group 1c, 2c, part of 3a, and Betula pumila. It is striking that the sociological amplitude of group 1c shows the same range as it does in the Kalmio-Chamaedaphnetea, probably because of similar moisture conditions.

Compared with the Bidenteto-Typhetum latifoliae, the appearance of species from group 1 indicates that the habitat is increasingly deficient in nutrients. In spite of the features in common with the Carex mat, the Laricetum is definitely a later stage in the succession than the mat. The table shows floristic differences as well, for the Cariceto-Betuletum still has representatives from group 2a that are lacking in the Saliceto-Laricetum. This points perhaps to rather eutrophic conditions, because this group occurs also in the Bidenteto-Typhetum latifoliae. The Saliceto-Laricetum, however, shows strong ties with the Picea mariana forests (group 1d, 1e, 1f, 2f, $3 \mathrm{~b}$, and $3 \mathrm{c}$ ). These sociological groups accentuate the fact that generally the soil in the Larix forests shows a lower $\mathrm{pH}$ than the soil in the pioneer mat (Conway 1949). Species in all these groups thus respond first to base content of the soil. In contrast with this, the groups that unite the Saliceto-Laricetum with the Cariceto-Betuletum must be indicators of another factor-probably moisture, for Larix forests are usually as wet as sedge mats.

The Saliceto-Laricetum could have been combined with the Copti-Piceion to make a unit of higher rank, but union with the Cariceto-Betuletum is preferable because both have the conspicuous Betula pumila shrub layer. Moreover, Larix laricina may be present in the sedge mat, although widely spaced. Finally the Laricetum forest generally lacks upland species of group 8 and higher that are present in Picea mariana forests.

\section{Alliance 3: The Copti-Piceion}

This unit represents the final stage in the hydrarch succession. Because of the accumulation of organic matter, the environment is rather dry, so two groups of upland species occur: (1) ubiquitous species that occur in almost every upland vegetation type (group 8 ), and (2) upland species that are typical for conifer forests (groups $14,16-22)$.

Data from Conway (1949) indicate that the mean $\mathrm{pH}$ in Picea mariana forests is not lower than that found in Larix laricina forests, so the two lowland forest types, the Saliceto bebbionae-Laricetum and the Copti-Piceion, have many groups in common. Despite this, the CoptiPiceion has several species (of group $2 g$ ) that are characteristic for the whole alliance in this region. As a result the Copti-Piceion is one of the best-defined vegetation types.

The alliance may be divided into two associations, the Habenarieto-Piceetum and the Dryopterideto cristataePiceetum. The latter is characterized by group 4 , which contains species with a wide sociological amplitude in the eutrophic Fraxinetalia nigrae. Moreover, species from Typha marshes are more abundant, especially Impatiens capensis. The Dryopterideto cristatae-Piceetum thus might occur on more eutrophic sites than the HabenarietoPiceetum. Another feature that accentuates the differ- 
ence is the presence of groups $2 f$ and $2 c$ in the Habenarieto-Piceetum, which ties it to the Saliceto-Laricetum. Which ecological factor is reflected by these groups is unknown. In the Habenarieto-Piceetum almost no species from group 3 a occur, probably because of the extremely dry and acid character of the environment. In part of the Dryopterideto cristatae-Piceetum this group ( $3 a$ ) is present. The sociological groups $3 a, 3 b$, and $3 c$ probably are ecologically not very homogenous. A detailed environmental analysis therefore is not yet possible.

Thuja occidentalis is generally recognized as closely related ecologically to Fraxinus nigra (Gates 1942, Clausen 1957, Christensen, Clausen, and Curtis 1959). Indeed in the Copti-Piceion it coincides with group 4. thus stressing the more eutrophic character of that tree compared to Picea mariana. Oxygen, $\mathrm{pH}$, and specific conductivity in ground water in Thuja soils (Wilde and Randall 1951) affirm this. In the tables the vegetation types with Thuja occidentalis are not clearly represented by characteristic species combinations. Unlike the AlnoFraxinion they do not include the shade-intolerant group 5b. But they cannot be so easily distinguished from Picea mariana forests, which also include shade-tolerant species. In the Dryopterideto cristatae-Piceetum, Thuja may be the dominant tree, but here Picea mariana may be dominant with the same species composition. Some differences may be made by sociological group 3a. This pattern, however, is not exactly congruent with the presence of Picea and Thuja. Moreover, Thuja occurs in a relevé with a species composition otherwise found in Larix forests. In relevé 39 it is even associated with species from the Bidenteto-Typhetum. This relevé, however, originates from a site (Bohall Creek) close to the water's edge, where a Thuja forest might be degrading. These findings are in agreement with the opinion of Conway (1949) that Picea as well as Thuja may be dominant in less acid peat. According to her, Picea mariana is not acidophilous but can tolerate acidity to a degree impossible for Thuja. On less eutrophic sites Thuja thus is absent (Habenarieto-Piceetum). On more eutrophic sites it is a matter of chance rather than environment which tree becomes dominant. In our region Thuja is not present on the uplands.

The difference in species composition between the Copti-Piceion and the Piceeto-Chamaedaphnetum agrees well with a species list given by Heinselman (1963) for poor and good spruce sites. The Copti-Piceion resembles Heinselman's black spruce-alder-herb type, but there is no relationship with his black spruce-feather moss type, because of the absence of several species from groups $3,14,17$, and 22-species that may be common in the Copti-Piceion.

The group of relevés labeled "transition" in the table poses a problem. Here are mixtures of Picea, Larix, and Thuja forests that show in the understory quite a bit of Chamaedaphne calyculata and Andromeda glaucophylla. This and the location of the releves in the Myrtle Lake area would favor arrangement in the Kalmio-Chamaedaphnetea, although Kalmia polifolia is absent. The presence of several species from groups 2 and 3, however, would point towards the "ThelypteridetoPiceetea." In this assignment, the block of relevés would fit best between relevés 54 and 55 . The block is better placed immediately after the Kalmio-Chamaedaphnetea, however, mainly because they have the same geographic location. Leaving it out of the 'Thelypterideto-Piceetea' then results in a better picture of the succession in the Itasca transect. Part of the Chamaedaphne vegetation of Segadas-Vianna (1955) from Quebec and Ontario may be placed in this transitional group on account of the joint occurrence of species from groups $1 \mathrm{~b}$ and 2 .

It is surprising that Chamaedaphne scarcely occurs in relevés of the Itasca transect. It is a very acidophilous species. According to Conway (1949), it does not occur in areas with a $\mathrm{pH}$ above 5.0, and it is not shade tolerant. As soon as Larix becomes dense, Chamaedaphne is shaded out and is replaced by Ledum groenlandicum. The same relations have been observed in the Kalmio-Chamaedaphnetea. As a result Chamaedaphne is greatly encouraged in open situations, often after disturbances such as fires (Catenhusen 1950). Our Larix and Picea forests might be too dense for Chamaedaphne. Conway points out, however, that an increase of Chamaedaphne happens only when the pH is low enough already. This would explain why our Cariceto-Betuletum, which is very open but not acidophilous enough, does not contain moss heath species like Chamaedaphne. In the Itasca State Park area there is a possibility that Chamaedaphne does not get a chance to establish itself because of the absence of such disturbances.

It is tempting to compare the Piceto-Chamaedaphnetum with oligotrophic ombrogenous bogs of western Europe. Raised bogs, like the Piceto-Chamaedaphnetum, are poor in species. But in Atlantic Europe no trees occur. The later stages of the succession in the Itasca transect might be compared with the more eutrophic Sphagmo-Alnion and Betulion pubescentis types in western Europe. Except for the trees Larix and Picea, which are unusual in a bog in western Europe, we find in both continents several ecological equivalents, e.g. Betula pubescensBetula pumila, Frangula alnus-Rhamnus alnifolia, and Alnus glutinosa-Alnus rugosa. Even some of the species are the same, e.g. Menyanthes trifoliata, Potentilla palustris, Oxycoccus quadripetalus, Caltha palustris, and the more eutrophic Dryopteris thelypteris, Lysimachia thyrsiflora, and Calla palustris.

The equilibrium between the environment and the species composition of the Larix laricina and Picea mariana forests in the Itasca State Park area is not a very stable one. Supply of nutrients may upset the delicate balance, turning the vegetation into more eutrophic types. These relationships may be seen at several places in the park area: in small lowland areas there is a relation between the type of upland vegetation and the lowland vegetation. If the bog is surrounded by a deciduous type of forest, the runoff, rich in bases, results in a broad marginal vegetation of Fraximus nigra (e.g. at Bear Paw Peninsula). Pine forests, on the other hand, favor the existence of bog vegetation. Indications for the same relationships have been found in the bog history of a small pond during the last 4,000 years (Janssen 1967).

This also may be the reason that the finest examples of bogs are found within the park boundaries, where pine has been protected from the logging operations since the turn of the century. Many of the smaller depressions in Populus tremuloides woods or in cultivated areas are covered by eutrophic Typha marshes, Alnus lowland shrubs, or Fraxinus nigra forests. Such a change from a bog to a $T y$ pha marsh at the time of the logging of the pine forests may be seen in the above-mentioned historical vegetation study of a small pond.

Severe fires, droughts, and drainage of the basin all contribute to the destruction of the bog flora (Curtis 1959, p. 236, Catenhusen 1950). A striking example is part of Bog D in Itasca State Park. After the construction of a road the Larix trees close to the road died off, and 
eutrophic species, especially Alnus rugosa, expanded considerably.

\section{The Fraxinetalia nigrae}

The Fraxinetalia nigrae constitute lowland forests of Fraxinus nigra and Ulmus americana, occurring on azonal A-G soil profiles (Buell and Borman 1955, Fraser 1957). It may be characterized by sociological groups 3,4 , and 5 . No representatives of group 2 occur. Curtis (1959) describes these communities under "northern wetmesic forests." In his species list, however, a numbet of species from group 2 occur.

Two alliances may be recognized.

\section{Alliance 4: The Alno-Fraxinion nigrae}

This is the type of vegetation known as marginal fen (Conway 1949), recognized in Minnesota by Kell (1938). The Fraxinion nigrae occurs on shallow peat in the marginal zone between bogs or sedge mats and the upland, and it is present on peat at all sites where nutrients are available, e.g. along creeks. As might be expected the $\mathrm{pH}$ is neutral to slightly acid. In many cases the peat has been transformed into amorphous muck by oxidation (Curtis 1959, p. 238), and as a result the pollen grains in the peat are strongly corroded, often beyond recognition. The alliance is best characterized by sociological group $5 \mathrm{c}$. Species generally present in the "Thelypterideto-Piceetum" (group 3 ) are found. It has group 4 in common with the Dryopterideto cristatae-Piceion.

The alliance may be divided into two associations: the Fraxinetum nigrae (group 5a), in which Ulmus americana is absent, and the Ulmeto-Fraxinetum nigrae, in which group $5 \mathrm{a}$ is absent and Fraxinus nigra and Ulmus americana both share the tree layer. In this community, species from group $6 \mathrm{~b}$ and $6 \mathrm{c}$ begin to be present. This is a division easily observed in the field, for the Fraxinetum nigrae often forms a belt closest to the bog, whereas the Ulmeto-Fraxinetum usually is found close to the upland, often on wet mineral soils.

Lowland shrub of Alnus rugosa, also a community in a mucky environment rich in oxygen (Wilde and Randall 1951), possibly may find its most natural place in this alliance. A list of species occurring in alder thickets in Wisconsin (Curtis 1959) contains many that are typical for the Fraxinetalia nigrae. However, the Almus rugosa shrub vegetation has not been sufficiently studied to assure its proper place. It might arise in case of clear cutting of Fraxinus nigra forest or as an initial stage after bog destruction.

The Alno-Fraxinion is closely related to the European Alnion incanae, which may occur also on thin layers of peat. It shows among the dominant trees the same two genera, but also the same richness in ferns. It also occurs on gley soils (cf. also the Sanguinaria-Arisaema type of Wilde (1958) in Wisconsin).

\section{Alliance 5: The Laporteo-Ulmion}

This alliance is characterized by sociological group $5 \mathrm{~d}$. Although Fraxinus nigra still is important, Ulmus americana plays a bigger role in the canopy than in the preceding alliance. All the relevés come from the floodplain of the Wild Rice River in Mahnomen County, the only river in the area big enough to form a real floodplain. In none of the relevés was peat present in the uppermost layer of the soil, which is too young for the development of a profile. This situation is comparable to that in the European Alnion incanae and Ulmion communities. Unfortunately a line through the alliance divides it into parts with and without a number of general upland herbs. The part with these species (tentatively named Osmorhizeto-Ulmetum) even comprises groups 9 and 7b. This ties it to the Uvulario-Aceretalia. This connection is stronger and more consistent than that to the lowland communities. Groups $3 b, 3 d, 4$, and $5 c$ may be present in part of the Laporteo-Ulmion, but this happens in an inconsistent way. It is therefore not possible yet to distinguish clearly between the Fraxinetalia migrae and the Uvulario-Aceretalia. More relevés are needed to clear the systematic position of a possible Ulmion besides the Fraxinion. The species composition of this alliance and the Alno-Fraxinion resembles that of Dansereau's Acereto-Ulmetum laurentiaum and Aceretum rubri in Quebec (Dansereau 1959).

\section{Deciduous Upland Forests}

\section{The Uvulario-Aceretalia}

The Uvulario-Aceretalia may be described as forest types that generally are recognized as mesic deciduous forests of Tilia americana, Acer saccharum, Ulmus americana, Fraxinus pennsylvanica, Quercus rubra, Quercus macrocarpa, and Populus tremuloides. The species found in these communities have a generally southern distribution. The Itasca region is almost at the northwestern edge of the rich deciduous forests. The species composition is therefore much impoverished when compared with stands southeast from here, e.g. the Big Woods of Daubenmire (1936). Another reason for this impoverishment of the flora is that many of the mesic stands are in a young stage of development. About 50 years ago the coniferhardwood region was the object of extensive logging, which removed many of the pines from the uplands. This and the destruction of pine seeds by the fires favored an increase in the areal extent of Populus tremuloides, which spread easily from root suckers, and of Betula papyrifera (Spurr 1954, Buell and Buell 1959).

About 1920 protection against fires became effective, and tree species less well adapted to fires than pine have become increasingly important, such as Abies balsamea, Acer saccharum, and Tilia americana (Heinselman 1954). They form a closed canopy of young trees, above which the pines, Populus tremuloides, and Quercus macrocarpa may tower. Not all of these stands are in such a young stage. Some examples exist of mature forests in which no sign of such an overstory is present. These stands are found in protected sites -islands, peninsulas, or between neighboring lakes, where fires occur less frequently than elsewhere (see also Daubenmire 1936).

The deciduous forest formation of course has no 
overstory of pine, but here protection against fires has resulted in the same trend towards mesic conditions. Young mesic stands here often surround old trees of Quercus macrocarpa and Populus tremuloides (McAndrews 1966).

The order may be characterized by sociological group 9a.

\section{Alliance 6: The Ulmo-Tilion americanae}

This alliance comprises among the mesic forest types stands that are most pronouncedly related to the AlnoFraxinion. This is expressed in sociological group 6 . In groups $6 \mathrm{a}$ and $6 \mathrm{~b}$ we find species that have their main distribution in the Fraxinetalia and Ulmo-Tilion. Group $6 c$ connects only the Laporteo-Ulmion with upland forests, but the right side of the sociological amplitude of this group extends into the Tilio-Acerion.

Another feature that stresses the relation with the Alno-Fraxinion is the occurrence of group 18b, mainly Abies balsamea. This tree occurs in the Ulmo-Tilion, often in a lower tree layer below the canopy of Tilia and Ulmus. Seedlings of Abies also are often present.

Group 7 may be called typical for the alliance, especially group $7 \mathrm{~b}$. Group $7 \mathrm{a}$ shows a main distribution in this alliance, but it extends also in the Tilio-Acerion.

It must be stressed, however, that most of these groups are not restricted to the Ulmo-Tilion. Some extend into the Tilio-Acerion, and several are found in rich QuercusPopulus forests. Many stands are not in a juvenile stage but contain mature trees. An overstory of pines or aspens is absent. Often we find these stands near lakes, which may prevent extreme air temperatures (Rosendahl and Butters 1928). The difference from the Tilio-Acerion may be explained also by soil differences. Buell and Bormann (1955) describe a Tilia-Abies-Fraxinus nigra stand on an A-G soil. This is common in Fraxinus nigra forests, but in this case Tilia is associated with it. It is therefore not impossible that the Ulmo-Tilion is best developed on such soils. It also would explain the floristic connection with lowland forests in a most natural way. Two stands in the Itasca region occurred on sandy soil rather than on till soil. The Tilio-Acerion then would occur on the better drained soils.

The alliance has been divided tentatively into two associations on the basis of group 6b (excluding Ulmus americana). In the Matteucieto-Tilietum group $6 \mathrm{~b}$ is present, but it is absent in the Uimeto-Tilietum americanae. However, it must be readily admitted that this basis is too narrow to support strongly the delimitation of these associations. There is a possibility that some of these stands are relics from a deciduous forest that preceded the present mixed forest (McAndrews 1966). Pollen analysis of a small pond in this forest type would settle this. There is one on the Bear Paw Peninsula.

The alliance resembles the Aceretum saccharophoriUlmosum of Dansereau (1959).

\section{Alliance 7: The Tilio-Acerion sacchari}

In this alliance Acer saccharum is the dominant tree, along with Tilia americana and Quercus rubra. It is usually a young forest, with the preceding stage of Pinus strobus and/or Populus tremuloides-Quercus macrocarpa still present (Buell and Cantlon 1951). Some of the relevés even contain herb species associated with an earlier stage (see alliance 8 ).

Notwithstanding the immature stage of the stands, the alliance is clearly defined by sociological group 11 .
Group 10 (also present in the Smilacino-Quercion) and group 9b (also present in the Ulmo-Tilion and SmilacinoOuercion) reach highest values here. Because of the dense character of these forests, the shrub and herb layers are not well developed. In these layers often the most abundant plants are seedlings of Acer saccharum itself. Seedlings of Tilia, however, are fairly rare.

The alliance comes closest to the southern mesic forest of Curtis (1959), which occurs between prairie and conifer-hardwoods in Wisconsin, and to the Big Woods in south-central Minnesota (Daubenmire 1936). These forest types, as well as the Tilia-Acerion, are characterized by Acer saccharum and Tilia americana as their major dominants. Also, they lack Tsuga canadensis and Betula lutea, which are typical constituents of the forest to the east and northeast. However, in the Itasca area this forest type is much impoverished: Carya, Celtis, and Juglans, for example, are absent. The Big Woods contain most of the species found in the Tilio-Acerion, but they also show species that in the Itasca region are optimal in the Ulmo-Tilion or even in the Fraxinetalia (e.g. Cryptotaenea canadensis, Laportea canadensis).

\section{Alliance 8: The Diervilleto-Quercion}

This alliance comprises forests of Populus tremuloides, $P$. grandidentata, Quercus macrocarpa, and $Q$. rubra. Tilia americana is less common than in the Ulmo-Tilion and Tilio-Acerion. The group of species that comes to full development here is sociological group 13. The number of shrubs is high. As a whole group 13 therefore may be typified as a group comprising pioneer species. Several species are known to reach their optimum in the regeneration shrub stages after clearing of a forest, e.g. Rosa and Rubus are important on abandoned fields. Corylus americana is an important shrub at the prairie-forest margin (McAndrews 1966) in a Quercus macrocarpa savanna. All of these shrubs give their forests a young, secondary character.

In a number of relevés Pinus strobus or Populus tremuloides comprises the overstory, but never Pinus resinosa.

The species of group 13 are not present throughout the two alliances. From right to left in the table, in the direction of the Tilio-Acerion, more and more species of group 13 drop out. Group 13 can be divided into a number of subgroups along this line. In the Tilio-Acerion at last most of the species of group 13 are absent, except group 13a-1, which comprises the species that are most likely to persist, namely the overstory species. The table shows also that at the same time conditions are increasingly mesic. Two suballiances are recognizable, the Smilacino racemosae-Quercion and the Uvulario-Quercion.

The Smilacino racemosae-Quercion is characterized by group 9a (the group typical for the Uvulario-Aceretalia), and by at least one other mesic group that is present also in the Tilio-Acerion. This suballiance may be divided into the Sanguinarieto-Populetum (group 9b) and the less mesic Querceto-Populetum tremuloides (group 10). Seedlings of Acer saccharum may be present, though not in such quantities as in the Tilio-Acerion. The divisions in the Smilacino racemosae-Quercion may be considered as steps in a succession leading towards the highly mesic Tilio-Acerion. In Populus and Quercus forests on good sites and in some Pinus strobus forests, protection from fires would result in an increase in the number of mesic species and at the same time an elimination of the pioneer fire species. Indeed Pinus strobus is generally considered as among the pines occurring on the better sites, with loams 
or sandy loams rich in bases (Curtis 1959). The succession from these pioneer forests towards the mesic Tilio-Acerion happens in the conifer-hardwood formation but also in the deciduous forest belt on the Big Stone Moraine, which is marked by soils especially favorable for mesic forest types. In fact, relevés from this area are heavily represented in the Smilacino racemosaeQuercion. Successions there since the federal land survey have been studied by McAndrews (1966).

The time elapsed since fires were a major ecological factor is short, and in the present Tilio-Acerion an overstory of Populus, Quercus, and Pinus strobus is still present. Pioneer species from this former forest are almost gone, however. An overstory of white pine above a nearly closed forest of mesic species also has been reported from northern Wisconsin (Curtis 1959, p. 212).

The Uvulario-Quercion can be divided into the Uvularieto-Populetum and the Corneto canadensis-Populetum. The first association is unspecific. It comprises group $9 \mathrm{a}$, characteristic for the order to which it belongs, and in addition only general upland forest species (groups 8 and 13). The Corneto canadensis-Populetum, however, shows for the first time a group of species (14) that more commonly occur in coniferous forest, though coniferous trees are generally absent. Moreover, besides Quercuas macrocarpa and Populus tremuloides, the association is characterized by Quercus rubra in the canopy and $A c e r$ rubrum in the shrub layer (group 13a-2). Acer rubrum less often attains tree size: Quercus forests containing Acer rubrum trees are more commonly found in the deciduous belt south of our area, but there it includes Ostrya virginiana.

The Corneto canadensis-Populetum occupies a position exactly between coniferous forests (group 14) and the mesic deciduous forests (group 9a). Analogues in Quebec are the Quercetum albae and Quercetum boreale (Dansereau 1959).

\section{Coniferous Upland Forests}

This group of communities has most genera and several species in common with the European Vaccinio-Piceetea Br.-B1. 39. We have here a parallel class that might be called Vaccinio- $P$ iceetea boreo-americana (Braun-Blanquet 1959). The sociological group that is characteristic for most of the coniferous forests is group 16.

Two orders may be recognized, namely the Corno canadensis-Pinetalia, characterized by group 14, and the Arctostaphylo-Pinetalia, characterized by group 21 . Braun-Blanquet recognizes the Vaccinio-Piceetalia in Europe, Asia, and northern North America and the Gaultherio-Piceetalia in the northern United States and southern Canada. The latter order includes more representatives of the Ericaceae than the former. According to this our two orders are equivalent to the units described by Braun-Blanquet. However, there are differences in species composition. Although no characteristic species of the Gaultherio-Piceetalia are given by Braun-Blanquet, the order seems to show a similarity to the Copti-Piceion of this study. It therefore seems better to apply new names for the orders described here. Because of the presence of conifers, the class is confined to the conifer-hardwood formation.

\section{The Corno canadensis-Pinetalia}

\section{Alliance 9: Populo-Quercion}

This alliance consists of forests of Populus tremuloides, Quercus macrocarpa, and Pinus banksiana. Compared with preceding communities, it has much less Quercus macrocarpa, however. Pinus banksiana may play a large part in the canopy of the forest, but it does not form pure stands. It is combined with either Populus tremuloides or Pinis strobus. Coniferous trees may even be absent, but relevés showing this composition are included in the order because they include groups 14,15 , and 16 , which are typical of most coniferous forests. Only one association could be distinguished, the Galieto-Populetum, on the basis of group 16.

Several relevés of Populus tremuloides forests lack representatives of group 16, so they have not been included in the Galieto-Populetum. They do belong within the Corno canadensis-Pinetalia, however, because group 14 is present, but group 9a of the Uvulario-Aceretalia is not.

The Populo-Quercion is the richest alliance in the order. Pinus strobus may be present, even dominant; in these cases group 9a may occur. It is the only alliance in the order in which group 13a is present. The PopulusQuercus forests in the Diervilleto-Quercion and the Populo-Quercion alliances have the same tree dominants, but floristically they seem to be tied to either the rich mesic deciduous forests or to the coniferous forests.

A similar situation exists in Michigan (Benninghoff and Cramer 1963) where Populus grandidentata forests show, besides relics of pioneer vegetation, species characteristic for poor and good sites. Gates (1930) described Populus stands with a species composition typical for "pine lands" and "beech maple soils." In Minnesota and Wisconsin this relation has been amply discussed by Kittredge (1938). It has been a point of frequent discussion in the past whether this part of the state is heading for an Acer saccharum-Tilia americana or an Abies balsamea-Picea glauca climax (Buell and Gordon 1945, Buell 1956, Buell and Martin 1961). According to Kell (1938) Acer forests would develop in fine-textured soils and Abies-Picea forests on coarser textured ones. There is in a general way a soil difference between the PopuloQuercion that tends to occur on sandy till or outwash and the Smilacino-Quercion on the heavier till of the Big Stone Moraine; but soil data from each individual relevé are needed to settle this.

Pteridium aquilinum is especially abundant in the Populo-Quercion and in the next alliance, the Pinion resinosae-banksianae. This is also true in Populus forests in lower Michigan (Gates 1930) and in the Populetum tremuloides, Betuletum papyriferae, and Betuletuon populifoliae in Quebec (Dansereau 1959), which are also pioneer forests that offer much light to the ground flora.

The Populo-Quercion may be considered as a vicariant of the European Vaccinio-Quercion.

\section{Alliance 10: The Pinion resinosae-banksianae}

This alliance, which consists of forests of $P$ imus resinosa and/or $P$. banksiana, is floristically difficult to define. The only species that differentiate it from the PopuloQuercion are the two species of group 17, including Pinus 
resinosa itself. The other groups present in this alliance occur in the Populo-Quercion as well.

In contrast to Pinus strobus, the two other pine species are less shade tolerant, but they are better adapted to the drier sites, which show a lower base content. As a result, these stands of pine are usually found on sands or loamy sands (Rudolph 1957). Pinus banksiana extends farther to the nutrient-deficient dry portion of the gradient than $P$. resinosa.

Most of the present mature $P$ inus resinosa forests that are protected in Itasca State Park belong to this type. They are widely recognized as a pioneer forest maintained by fires (Spurr 1954). This also applies to most of the Populus forests. Moreover, the Pinion resinosaebanksianae and the Populo-Quercion occur on the same soil types. These features in common may help to explain why the floristic differences between the $P$ inion resinosae-banksionae and Populo-Quercion are so small. The only difference is the occurrence of the dominant $P$ inus resinosa. The two species are alternately dominant in the same community, according to Curtis (1959, p. 469), as a result of the lower intensity of presettlement fires, which did not destroy pine seeds of Pinus resinosa and $P$ inus strobus in the same manner as the heavy slash fires did during lumbering of the pine forest. Reproduction of the pine forest today seems to be difficult because of protection from mild fires (Spurr 1954). The species composition of the Pinion resinosae-banksianae does not exclude a possible succession towards an Abies balsamea forest.

\section{Alliance 11: Abietion balsameae}

Abies balsamea and Picea glauca forests are usually at a very young stage in development. Seedlings and saplings of Abies are very abundant, and all the stands of this type are reproducing vigorously. Floristic ties with the Pinion resinosae-banksianae are still strong. Some of the relevés show a similar species composition except for Abies balsamea and Picea glauca, which occur in all the layers of the forest except the highest one-still occupied by Pinus resinosa (exclusively in this alliance) or Pinus strobus. This relationship with a former pine stage appears to exist in all the sites occupied by $A b i e s$ forest type. A site that has been continuously occupied by Abies balsamea virtually does not exist (Buell and Niering 1957).

In part of the Abietion balsameae the pioneer sociological group $13 \mathrm{~b}$ is still present. In the more advanced stages, however, several species occur that are characteristic for Abies forests in this part of the state (group 20). On the basis of this the Trientaleto-Abietum has been recognized. Some of the immature stages then may be arranged under the Abietum balsameae rosetosum, indicating the strong pioneer character of these forests. In the most advanced stage group 13b has gone, and we find a renewed occurrence of two species of group 3 that occur on peat (see also Buell and Niering 1957). The appearance of these species on mineral soil may be explained by the increasing dampness of the vegetation, probably related to the dense cover of these forests.

It is not surprising that group $13 \mathrm{~b}$ is absent. As mentioned already, this group constitutes a pioneer group adapted to heliophilous conditions. Because of the shade of Abies this group is the most likely one to go. There is also a decrease in importance in group 8. A subassociation Abietum balsameae mitelletosum has accordingly been recognized.

\section{The Arctostaphylo-Pinetalia}

In contrast to the Abietion balsameae, where light is a limiting factor, in this order soil is limiting. The Arctostaphylo-Pinetalia occur on dry outwash sands. Pinus banksiana is almost the only tree present. The characteristic groups are $21 \mathrm{a}$ and $21 \mathrm{~b}$, the latter to a less extent. The outwash sands on which the order occurs belong to the mineral soils with the lowest nitrogen and moisture content. Also they show a low pH (Allway and McMiller 1935). The divisions in the order are probably a result of these soil factors.

\section{Alliance 12: The Astero-Pinion}

In this alliance sociological group 8c drops out of the general upland forest species. Also group 14, characteristic for most of the coniferous forests in the area, is absent. It is found at the margin. of the Lake George outwash plain or in smaller occurrences of outwash sand in the region.

\section{Alliance 13: The Krigio-Pinion}

In the Krigio-Pinion more general upland forest species disappear (group 8b). The only ones that remain are Fragaria vesca/virginiana and Maianthemum canadense (group 8a). Most of the shrub layer so conspicuous in the preceding communities has gone, and the poor edaphic conditions even affect Pinus banksiana itself, which becomes more widely spaced. The understory is characterized by a low heath of ericaceous shrubs, in which lichens are common. At the same time a set of new species appears, among which are several dry prairie species.

Releves of this type are all situated in the center of the Lake George outwash plain east of Itasca State Park. This area constitutes the most extensive outwash plain in the region. According to Allway and McMiller (1935), in a comparable area in the southern part of the county the federal land survey recorded Pinus banksiana forest in 1860 but prairie in 1871. It is not impossible that fire is the main reason for such a shift in vegetation type, for Pinus banksiana is a tree highly adapted to fire for its reproduction (Rudolph 1958). Perhaps at the same time fires also swept the Lake George outwash plain, returning much of the forest to prairie or pine savanna. The prairie species present in the Krigio-Pinion may be considered as relics from this period.

Two associations may be recognized in the order: Krigieto-Pinetum, characterized by group 21d, and the Senecio-Pinetum, in which group $21 \mathrm{~d}$ is absent but groups $21 \mathrm{~b}$ and $21 \mathrm{c}$ are present.

The order resembles in species composition the Pinetum banksiana in Quebec, where it occurs on the same soil types (Dansereau 1959). Dansereau also mentions the infiltration of prairie elements from the west. Towards the north in boreal and arctic regions this community becomes mixed with species from the Copti-Piceion (Ledum groenlandicum, Picea mariana), e.g. Piceetum ledosum 
(sensu Dansereau). In the Upper Midwest this type is found in southeastern Manitoba (Ritchie 1961), where Ledum groenlandicum occurs especially on gley soils with a high water table. In our region this usually is not so, but because of the location of these vegetation types in low-lying plains a high water table might affect the minor vegetation. The rare occurrence of Ledum in a Pinus banksiana stand just north of Itasca State Park might be explained in this way.

In Ritchie's study Arctostaphylos uva-ursi and Lithospermum canescens (A) are present on dry soils. Linnaea borealis and Pteridium aquilinum (B) do not occur on the driest soils. Cornus canadensis and Vaccinium myrtilloides (C) come third in tolerance to moisture deficiency. This behavior is also reflected in the table of the Vaccinio-Piceetea. Group A is characteristic for the Arctostaphylo-Pinetalia, group B constitutes species absent in the Krigio-Pinion, and group C has species that are even absent in the order.

The divisions of the order of the ArctostaphyloPinetalia probably thus reflect differences in soil moisture superimposed on the general deficiency of nutrients. The Krigio-Pinetum in such a scheme would be extremely dry. The same dependency towards soil moisture has been reported by Stallard (1929). According to him, the water content of the superficial soil in stands with shrubs (AsteroPinion) is higher than that in Pinus banksiana stands without shrubs (Krigio-Pinion).

\section{ACKNOWLEDGMENTS}

The field data of this survey were collected during the tenure of National Science Foundation Summer Fellowships at the Lake Itasca Biological Station, whose director, Dr. W. H. Marshall, made available the facilities of the station. Much of this study would not have been possible without the support of many people who helped the author with flora and vegetation, so different from that of his home country. Dr. G. B. Ownbey and Dr. J. W. Moore of the Department of Botany, University of Minnesota, and Dr. R. F. Thorne, University of Iowa, helped in the identification of plants found in the relevés. $\mathrm{He}$ is especially indebted to Dr. J. H. McAndrews, who joined him in the field on numerous occasions and introduced him to the flora and vegetation of northwestern Minnesota. He is also grateful to Dr. V. Westhoff of the State Institute for Nature Conservation Research, Zeist, Netherlands, and to Dr. E. J. Cushing, Dr. Egolfs Bakuzis, and Dr. J. W. Moore of the University of Minnesota, who offered fruitful discussions and kindly criticized the manuscript. Above all the author owes much to Dr. H. E. Wright, Limnological Research Center, University of Minnesota, who made it possible for the author to spend so much time in the field, in spite of the fact that he came to Minnesota for palynological purposes, and helped in every possible way throughout his stay in the United States.

\section{Literature Cited}

Allway, F. J., and P. R. McMiller. 1935. The soils of Hubbard County, Minnesota. Univ. Minn. Agr. Exp. Sta. Bull. 317. 111 p.

Arneman, H. F. 1963. Soils of Minnesota. Univ. Minn. Agr. Ext. Serv. Bull. 278. 8 p.

Bakuzis, E. V. 1960. Structural organization of forest ecosystems. Minnesota Acad. Sci. Proc. 27 (1959): 97-103.

Benninghoff, W. S., and K. J. Cramer. 1963. Phytosociological analysis of aspen communities on three site classes for Populus grandidentata in western Cheboygan County, Michigan. Vegetatio 11: 253-263.

Bergman, H. F., and H. Stallard. 1916. The development of climax formations in northern Minnesota. Minn. Bot. Stud. 4: 333-378.

Braun, E. L. 1950. Deciduous forests of eastern North America. Blakiston Co., Philadelphia. 596 p.

Braun-Blanquet, J. 1951. Pflanzensoziologie. Grundzüge der Vegetationskunde. Springer, Wien. 631 p. 1959. Grundfragen und Aufgaben der Pflanzensoziologie, p. 145-171. Im W. B. Turrill, Vistas in botany. Pergamon Press, London.

Bray, J. R., and J. T. Curtis. 1957. An ordination of the upland communities of southern Wisconsin. Ecol. Monogr. 27: 325-349.

Buell, M. F. 1956. Spruce-fir, maple-basswood competition in Itasca Park, Minnesota. Ecology 37: 606.

Buell, M. F., and F. H. Bormann. 1955. Deciduous forests of Ponemah Point, Red Lake Indian Reservation, Minnesota. Ecology 36: 646-658.

Buell, M. F., and H. F. Buell. 1959. Aspen invasion of prairie. Bull. Torrey Bot. Club 86: 264-265.

Buell, M. F., and J. E. Cantlon. 1951. A study of two forest stands in Minnesota with an interpretation of the prairie forest margin. Ecology 32: 294-316.

Buell, M. F., and W. E. Gordon. 1945. Hardwood conifer forest contact zone in Itasca Park, Minnesota. Amer. Midl. Natur. 34: 433-439.

Buell, M. F., and W. E. Martin. 1961. Competition between maple-basswood and fir-spruce communities in Itasca Park, Minnesota. Ecology 42: 428-429.

Buell, M. F., and W. A. Niering. 1957. Fir-sprucebirch forest in northern Minnesota. Ecology 38: $602-610$.

Catenhusen, J. 1950. Secondary successions on the peat lands of glacial Lake Wisconsin. Trans. Wisc. Acad. Sci. 40: $29-48$.

Christensen, E. M., J. J. Clausen, and J. T. Curtis. 1959 Phytosociology of the lowland forests of northern Wisconsin. Amer. Midl. Natur. 62: 232-247.

Clausen, J. J. 1957. A phytosociological ordination of the conifer swamps in Wisconsin. Ecology 38: $638-646$.

Conway, V. M. 1949. The bogs of central Minnesota. Ecol. Monogr. 19: 173-206.

Cooper, W. S. 1912. The climax forest of Isle Royale, Lake Superior, and its development. Bot. Gaz. 55: 1-44, 115-140, 189-235.

Curtis, J. T. 1959. The vegetation of Wisconsin. An ordination of plant communities. Univ. Wisconsin Press, Madison, Wisc. 657 p.

Curtis, J. T., and R. P. McIntosh. 1951. An upland forest continuum in the prairie-forest border region of Wisconsin. Ecology 32: 476-496.

Damman, A. W. H. 1964. Some forest types of central Newfoundland and their relation to environmental 
factors. Forest Res. Br. Contrib. 596, Forest Sci. Monogr. 8. 62 p.

Dansereau, P. 1959. Phytogeographia Laurentiana, 2. The principal plant associations of the St. Lawrence valley. Inst. Bot. Univ. Montreal Contr. 75. 147 p.

Daubenmire, R. F. 1936. The Big Woods of Minnesota, its structure and relation to climate, fire, and soils. Ecol. Monogr. 6: 233-268.

Doing, H. 1962. Systematische Ordnung und floristische Zusammensetzung Niederländischer Waldund Gebüschgesellschaften. Wentia 8. $85 \mathrm{p}$.

Donselaar, J. van. 1965. An ecological and phytogeographic study of northern Surinam savannas. Wentia 14. $163 \mathrm{p}$.

Duvigneaud, P. 1946. La variabilité des associations végétales. Bull. Soc. Bot. Belg. 28: 107-134.

Elleaberg, H. 1956. Grundlagen der Vegetationsgliederung. Teil 1: Aufgaben und Methoden der Vegetationskunde. Eugen Ulmer, Stuttgart. 136 p.

Fraser, D. A. 1957. Ecological studies of forest trees at Chalk River, Ontario, Canada, 1. Tree species in relation to soil moisture sites. Ecology 35: 406-414.

Gams, H. 1941. Ubber neue Beiträge zur Vegetationssystematik unter besonderer Berücksichtigung des floristischen Systems von Braun-Blanquet. Bot. Arch. 42: 201-238.

Gates. F. C. 1930. Aspen association in northern lower Michigan. Bot. Gaz, 90: 233-259.

1942. The bogs of northern lower Michigan. Ecol. Monogr. 12: 213-254.

Gleason, H. A. 1926. The individual concept of the plant association. Bull. Torrey Bot. Club 53: 7-26.

Goodall, D. W. 1954. Vegetational classification and vegetational continua. Angew. Pflanzensoziol. 1: 168182.

1963. The continuum and the individualistic association. Vegetatio 11: 295-316.

Heinselman, M. L. 1954. The extent of natural conversion to other species in the lake states aspenbirch type. J. Forest. 52: 737-738.

- 1963. Forest sites, bog processes, and peat-land types in the glacial Lake Agassiz region, Minnesota. Ecol. Monogr. 3: 327-374.

Hustich, I. 1955. Forest botanical notes from the Moose River area, Ontario, Canada. Acta Geographica $13(2), 50 \mathrm{p}$.

Iversen, Johs. 1954. Uber die Korrelationen zwischen den Pflanzenarten in einem Grönländischen Talgebiet. Vegetatio 5-6: 238-246.

Janssen, C. R. 1967. Stevens Pond : a postglacial diagram from a small $T y p h a$ swamp in northwestern Minnesota, interpreted from pollen indicators and surface samples. Ecol. Monogr. 37: 145-172.

Kell, L. L. 1938. The effect of the moisture retaining capacity of soils on forest succession in Itasca Park, Minnesota. Amer. Midl. Natur. 62: 682-695.

Kittredge, J. 1938. The interrelations of habitat, growth rate, and associated vegetation in the aspen community of Minnesota and Wisconsin. Ecol. Monogr. 8: 151-246.

Kurz, H. 1928. The influence of sphagnum and other bog mosses on bog reactions. Ecology 9: 56-69.

Lambert, J. M., and W. T. Williams. 1962. Multivariate methods in plant ecology. IV : Nodal analysis. J. Ecol. 50: 775-802.

Lee, S. C. 1924. Factors controlling forest successions at Lake Itasca, Minnesota. Bot. Gaz. 78: 129-174.
Looman, J. 1963. Preliminary classification of grasslands in Saskatchewan. Ecology 44: 15-29.

Maycock, P. F., and J. T. Curtis. 1960. The phytosociology of boreal conifer-hardwood forest of the Great Lakes region. Ecol. Monogr. 30: 1-35.

McAndrews, J. H. 1966. Postglacial history of prairie, savanna, and forest in northwestern Minnesota. Mem. Torrey Bot. Club. 22(2). 72 p.

McIntosh, R. P. 1958. Plant communities. Science 128: $115-120$.

Moss, E. H. 1953. Marsh and bog vegetation in northwestern Alberta. Can. J. Bot. 31: 448-470.

Foore, M. E. D. 1955a. The use of phytosociological methods in ecological investigations. 2. Practical issues involved in an attempt to apply the BraunBlanquet system. J. Ecol. 42: 245-269.

- 1955b. The use of phytosociological methods in ecological investigations. 3. Practical applications. J. Ecol. 43: 606-651.

Ritchie, J. C. 1960 . The vegetation of northern Manitoba. 1. The lower Hayes region. Can. J. Bot. 38: $769-788$.

-2. 1961. Soil and minor vegetation of pine forests in southeast Manitoba. Can. Dep. Forest., Forest Res. Div. Tech Note. 96. 21 p.

Rosendahl, C. O., and F. K. Butters. 1928. Trees and strubs of Minnesota. Univ. Minnesota Press, Minneâpolis, Minn. $385 \mathrm{p}$.

Rowe, J. S. 1959. Forest regions in Canada. Can. Dep. Northern Affairs and National Resources, Forest. Br., Bull. 123. 71 p.

Rudolph, P. O. 1957. Silvical characteristics of red pine. Lake States Forest Exp. Sta., Sta. Pap. 44. $32 \mathrm{p}$.

- 1958. Silvical characteristics of jack pine. Lake States Forest Exp. Sta. Sta. Pap. 61. 31 p.

Scamoni, A., and H. Passarge. 1959. Gedanken zu einer natürlichen Ordnung der Waldgesellschaften. Arch. Forstwesen 8: 386-426.

Segadas-Vianna, F. 1951. A phytosociological study of cattail stands in Oakland County, Michigan. J. Ecol. 39: 316-329.

Spurr, S. H. 1954. The forests of Itasca in the 19th century as related to fire. Ecology 35: 21-25.

Stallard, H. 1929. Secondary succession in the climax forest formations of northern Minnesota. Ecology 10: 476-547.

Tüxen, R. 1955. Das System der nordwestdeutschen Pflanzengesellschaften. Mitt. Florist.-soziol. Arbeitsgemeinsch. N. F. 5: 155-176.

Veaver, J. E., and F. E. Clements. 1938. Plant ecology. McGraw-Hill, New York. 601 p.

Wilde, S. A. 1958. Forest soils: their properties and relation to silviculture. Ronald Press, New York. 537 p.

Wilde, S. A., and G. W. Randall. 1951. Chemical characteristics of ground water in forest and marsh soils of Wisconsin. Trans. Wisc. Acad. Sci., Arts, and Lett. 40: 251-259.

Williams, W. T., and J. M. Lambert. 1959. Multivariate methods in plant ecology. I: Association analysis in plant communities. J. Ecol. 47: 83-101.

1961. Multivariate methods in plant ecology. III : Inverse association analysis. J. Ecol. 49: 717729.

Wright, H. E. 1962. Role of the Wadena lobe in the Wisconsin glaciation of Minnesota. Geol. Soc. Amer. Bull. 73: 73-100. 